\section{Star wars unworkable}

\section{President Reagan's best friends should tell him that his star-wars scenario is an illusion.}

PRESIDENT Ronald Reagan's plan for a system of "star wars" defences against nuclear attack will not work. The scientific community, which the president asked a little over a year ago to invent the means of rendering nuclear weapons "impotent and obsolete", knows that it will not work, and has said so. The president's advisers, including his science adviser, Dr George Keyworth, know it too, but are afraid to say so. Instead, they have invented a different and more plausible version of what $\mathrm{Mr}$ Reagan wants in the hope that nobody will notice the difference. They will of course be found out; the danger is that they might get away with it for long enough to do substantial mischief to the cause of arms control.

\section{Revisionism}

The revisionist version of the star wars idea goes something like this: yes, it does seem rather difficult to think of a way to defend the US people against a nuclear attack, but there is no need to look for a near-perfect defence right away. As a first step, the United States might construct a star wars system that could shoot down a fair proportion of Soviet intercontinental ballistic missiles (ICBMs) launched against the United States in a nuclear war. Thus the degree of confidence with which the Soviet Union could launch a preemptive attack on US missiles would diminish; since they would have reason to fear American retaliation, deterrence would be strengthened. Later on, perhaps, the defensive system might enfeeble strategic nuclear weapons so much that they would become too unreliable to be used.

What is wrong with this argument? Plenty, as it happens. But the first thing to say is that it bears virtually no relation to what President Reagan actually said in his star wars speech 14 months ago. In that speech, the president did not propose a defensive system as a means of preserving the ability of the United States to retaliate against a Soviet preemptive strike, but as a way to make retaliation unnecessary. Here is what he said.

Up until now we have increasingly based our strategy of deterrence upon the threat of retaliation. But what if free people could live secure in the knowledge that their security did not rest upon the threat of instant US retaliation to a Soviet attack; that we could intercept and destroy strategic ballistic missiles before they reached our own soil or that of our allies?

There is nothing ambivalent about that; what the president proposed was a shield through which so few nuclear missiles could leak that the United States would not even have to threaten the Soviet Union with retaliation in the event of a nuclear attack. Is it feasible? Almost certainly not, for reasons that have been fairly and lucidly explained in a new report from the Office of Technology Assessment (OTA). The OTA study is especially significant because it was prepared with the benefit of full access to classified data by a body which is traditionally careful to avoid partisan stances. Even so, it found the prospect of a near-perfect defence "so remote that it should not serve as the basis of public expectation or national policy"'.

\section{Pessimism}

The reasons for pessimism are clear. At least part of a successful defensive array would have to be based in space, where it would itself be hopelessly vulnerable; even if it could somehow be protected, the defensive system would have to shoot at so many boosters, warheads and decoys that its data-processing requirements would be far beyond what is presently imaginable; none of the weapons yet proposed are based on mature technology, whereas countermeasures are; to destroy Soviet missiles before they could deploy their multiple warheads would require such an instant response that a decision to activate the system might have to be taken by machines rather than people.

The biggest flaw, however, is that the principal characteristic of nuclear weapons - the ability of tiny objects to cause massive destruction - continues to make a nonsense of the notion of a "near-perfect" defence. There are, and there always have been, some respectable arguments for defence. After all, the difference between an attack in which 250 megatonnes were detonated over the United States and an attack in which only 5 megatonnes (about one two-thousandth of the Soviet arsenal) got through cannot be ignored. While the former could kill half the population and injure most of the rest, the latter, if cities were preferentially targeted, could kill several million people and injure 10 million more. The scores of millions saved by the successful interception of the 245 megatonnes would have reason to be grateful, but could hardly regard the destruction of the most great cities and the death of millions of their fellows as a near-perfect defence. The temptation to retaliate - and the need to deter would remain.

So the president's vision of a future in which a leakproof defence makes nuclear weapons obsolete and the threat of retaliation unnecessary is a vision that cannot be given technical expression. The taxpayers of the United States employ people whose job it is to keep the president informed about the limits of technology. Dr Keyworth is one of them. Sadly, there is no evidence that he is willing to give Mr Reagan the bad news; indeed, there are disquieting signs of a witch hunt against those scientists who have spoken out honestly. Some have been accused of defeatism, others of disloyalty. It is, however, an entirely misguided sense of loyalty that has persuaded the revisionists to fudge the issue by arguing that if "star wars" cannot defend everything they can at least defend our ability to retaliate. That is a travesty of the promise President Reagan held out in his speech on $23 \mathrm{March}$, and an argument that will do him no good politically. Neither Congress nor the general public will be pleased to discover that the panacea in which they have been asked to invest billions of dollars is intended as the strategic equivalent of a hardened silo.

\section{Dishonesty}

That is why the revisionist argument is dishonest. But is it wise? There is in general something to be said, as Freeman Dyson argues in his recent book, Weapons and Hope (Harper \& Row, New York and London), for the moral superiority of defensive weapons. Here the arguments for star wars and for civil defence converge; it is worth trying to save the lives of some even if it is not possible to save the lives of all. The snag is that no policy or action in the domain of nuclear weapons takes place in a vacuum; each increases or diminishes the likelihood of a war being fought with nuclear weapons. There is unfortunately little reason to believe that possession of star wars defences will diminish the likelihood of war, and some reason to believe it will increase it.

That is because neither side, faced with the development of a defensive shield by the other, will acquiesce in the president's aim of making nuclear weapons "impotent and obsolete". Instead, by deploying a defensive shield of impressive but imperfect capabilities, each side gives the other an extra reason to strike first; the shield will be less effective against an unexpected massive first strike than it will against a ragged retaliation by the survivors of an attack. Nor will the shield necessarily save lives. A superpower confronted with a star wars defence could decide to aim a higher proportion of its missiles at cities to preserve its ability to deter. Finally, the development of a star wars system makes the chances of reducing the number of nuclear weapons increasingly remote; if your enemy has a shield you need more arrows.

It is argued by some that even if the defensive notion turns out to be neither feasible nor desirable, there is no harm now in pursuing the research that will keep the United States' options open in the future. The harm, of course, is in allowing the quest for rational progress on arms control to be delayed by the search for technical panaceas; in believing that the next weapon or gadget you invent will make its predecessors redundant. Vide $\mathrm{Dr}$ Keyworth testifying on star wars research to the Senate Foreign Relations Committee last month: "While I see absolutely no need to violate any provision of existing treaties while we investigate these options, I am very leery of entangling ourselves in future treaties until we know more". 